\title{
SELF-REPRESENTATION, VIOLENCE AND PERIPHERY IN CAPÃO PECADO
}

\author{
Keury Carolaine Pereira da Silva \\ Universidade Estadual do Maranhão - UEMA (Brazil) \\ keurycarolaine@outlook.com \\ Emanoel Cesar Pires de Assis \\ Universidade Estadual do Maranhão - UEMA (Brazil) \\ emanoel.uema@gmail.com
}

Received: 03/12/2019 - Approved: 11/03/2020

DOI: doi.org/10.17533/udea.lyl.n78a15

\begin{abstract}
This research analyzed how the search for self-representation in literature claims the presence of peripheral groups and differs in the specificities of language and aesthetics, such as the case of violence in the work Capão Pecado, by Ferréz. Therefore, the considerations about this theme were expressed, from the perspective of those who practice and are the target of this impetus. In order to reach the scope of this research, some theorizations were considered. Finally, it is considered that the book suggests a reflection about the common perceptions of favelas and their residents, by providing new views of them.
\end{abstract}

Key words: Brazilian literature; violence; periphery; Capão Pecado; self-representation.

\section{AUTORREPRESENTAÇÃO, VIOLÊNCIA E PERIFERIA EM CAPÃO PECADO}

Resumo: Esta pesquisa analisou como a busca pela autorrepresentação na literatura reivindica a presença de grupos periféricos e difere nas especificidades da linguagem e estética, como o caso da violência na obra Capão Pecado, de Ferréz. Portanto, as considerações sobre este tema foram expressas, na perspectiva daqueles que praticam e são o alvo desse ímpeto. Para chegar ao escopo desta pesquisa, foram consideradas algumas teorizações. Por fim, considera-se que o livro sugere uma reflexão sobre as percepções comuns das favelas e seus moradores, fornecendo novas visões sobre elas.

Palavras-Chave: literatura brasileira; violência; periferia; Capão Pecado; autorrepresentação. 


\section{Introduction}

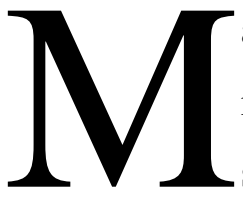

arginal literature brings themes related to living in a geographical locus, in this sense, difficulties appear related to the representation of the subordinate classes that, in the fictional field, are interpreted and narrated based on the perspective of authors from classes opposed to the characters described. Speaking on behalf of other reproduces stereotypes that limit the ability and presence of certain social groups to the extent that established labels are accepted. In literature, the relation of meaning construction through prejudice is also observed; the stigma of the literary stereotype perpetuates the marginalization of certain individuals, being a kind of social proliferation that induces the silence of these groups in collective spheres.

However, it happens that representation, as Hall (1997) stated, is linked to the sense of culture and language. The author argues that social groups that share the same culture belong to «...the same conceptual and linguistic universe» (p. 22).

In the same way, Hall (1997), by introducing Foucault and the notion of discourse in his text, pointed out that the possession of power functions as the main mechanism of control of discourse and, consequently, representative practices called «stereotyped» emerge. Thus, we can understand that, from this aspect, the practice of representation by stereotyping characterizes the maintenance of power by the exclusion and closure of others. Hall (1997), however, warns that the representations are not fixed, and there are possibilities to change many stereotypes that are immutable in society.

Given this, if representation means speaking in the name of another, selfrepresentation would be the attempt to emerge voices long silenced, to speak for itself. In literature, it is possible to observe this mobilization of breaking the previously prevailing social structure, albeit sparingly, it is feasible to reconstruct the paths and direct at least a fair dispute for the right to voice in today's society. Thus, literature acts as an essential figure in this search for balance, enabling opportunities. Therefore, the problem itself is not literary representation, but validating as coherent and acceptable only one side and consequently excluding the other.

The aesthetic of self-representation rediscovers reality from the perspective of those who had not even participated in the dispute for the right to voice. Given this, the literary works produced by a society, which speaks of itself, reflect, in its own way, 
contemporary social relations. The suburban intellectuals have gained access to the spheres of power and now assume the task of portraying one's self in the way that suits them, either by the slum speech or even by the rural speech of the poor Brazilians northeasters. The self-representing writers then became aware that they assumed the representation of their own nuances and subverted the discourse of power, resulting in a decentralization of discourse.

Thus, the subordinate, in producing literature, uses a significant authority that conquers expressive paths that emanate from an enunciative place proper to the excluded. Therefore, to claim a subversive position before the representations of power is, above all, to express one's own discourse, while also demonstrating resistance.

From this angle, the literary production of Reginaldo Ferreira da Silva «Ferréz» constitutes a narrative of resistance and legitimation, since the author grew up in the Capão Redondo favela, located in the city of São Paulo, known for its high levels of violence. Despite this feature, the author claims that the center's gaze turns to the suburb and its loud culture: graffiti, rap and literature.

Reginaldo Ferreira da Silva, or under his pen name «Ferréz», appears as an important name in this scenario. The nickname is derived from a hybrid that pays tribute to two great personalities: Virgulino Ferreira and Zumbi dos Palmares. He is the author of Manual Prático do Ódio (2003), Ninguém É Inocente em São Paulo (2006), and Deus Foi Almoçar (2012). Previously, the author gained fame in the literary market through his work Capão Pecado (2000).

It was through the reception that Capão Pecado obtained, that the peripheral author engaged in other artistic projects. In this sense, Nascimento (2006) stated that Ferréz began to write monthly for the Caros Amigos magazine since the 2000s, something important for the recognition of the writer in the national field, and especially for him to get the sponsorship for launching other authors « com o mesmo perfil sociológico (originários das classes populares e moradores ou ex-moradores das periferias urbanas brasileiras) no projeto de "literatura marginal" em revista » (p. 16).

So, Ferréz's initiative is encouraging writers to consolidate the nomenclature of «marginal» for the literature produced by these «residents or former residents of the Brazilian urban peripheries», the marginal adjective being designated to the literary products produced by these individuals. By assuming this position, Ferréz has made 
peripheral neighbourhoods, which used to be known through the police pages, become home to a generation of writers dedicated to exposing the chaotic life in the favela through poems, short stories and novels. Therefore, mediating other voices based on the visibility obtained by the author is a strategy to build a collective and dialogical literary network that shares the same peripheral experience, which became known as marginal literature.

The peripheral author, as Ferréz is usually called, highlights the importance of assigning this nomenclature to the production created at the social margins, by providing geographical and social relations to designate the literature practiced at the margin.

Thus, the adoption of the «marginal literature» nomenclature establishes a literary production that arises in the midst of exclusion. Therefore, these authors reiterate the heterogeneous space in contemporary Brazilian literature. Schollhammer (2009) considered that works produced within this perspective, such as Ferréz's own collection of marginal literature, called Talents of Peripheral Writing (2005) «revelaram um fascínio em torno de vozes marginais, de uma realidade excluída, que agora exige seu espaço também na ficção» (pp. 98-99).

In these terms, Ferréz's expressive strength characterizes the resistance that the author exposes in all areas of his trajectory; the effort of the author consists in making the periphery stand out in the urban universe. What was previously considered to be of no value has now importance and also a positive evaluation. So, Ferréz reinforces the construction of a peripheral culture, by establishing in his attitudes a process of resignification of this environment.

Such marginality demarcates the history of many writers in contemporary Brazil. Unable to afford their publications, the marginal authors get together and struggle to conquer an editorial space in the marketplace. The culture of the periphery emerges from the streets, so naming this production as marginal is a reflection of the political position of writers who tell their stories in the community. Ferréz, in his manifesto for the opening of the book Literatura Marginal (in English, Marginal Literature), says that:

Estamos na rua loco, estamos na favela, no campo, no bar, nos viadutos, e somos marginais mas antes somos literatura, e isso vocês podem negar, podem fechar os olhos, virarem as 
costas, mas como já disse, continuaremos aqui, assim como o muro social invisível que divide esse país (Ferréz, 2006).

Patrocínio (2013) asserted that the marginal tendency is manifested by the expression of an individual who speaks from the point of enunciation, thus occupying the same place of what is said. The author brings out writers who follow this same path today, such as Ferréz, Alessandro Buzo, Sacolinha, Rodrígo Ciríaco, and others. In order to understand the literary production within this movement, it is necessary to use a wider reading, by taking into consideration the context beyond the text.

The collectivity is another significant aspect in Ferréz's literary composition. Undoubtedly, Capão Pecado uses that principle, by having in its conjuncture the collaboration of other authors. The writer's attitude enables changes related to the way minorities have been incorporated into contemporary literary representations. Ferréz, while narrating a collective experience, seeks elements in the community itself that characterize it as a collective space of experience, despite preserving individuality and the capacity for voice and representation in the personal sphere of each individual.

In this sense, Ferréz finds himself in a violent and unequal context, a problem especially related to the economic bias. This perspective, consequently, makes the author evidence such characteristics in his artistic productions, thus, his work denounces his own life experiences. Therefore, the attitude taken in this context is favorable to minorities, and the emergence of an individual and collective identity is identified in his narration.

Therefore, the author's narrative is part of a project of awareness regarding his own community. Capão Pecado reveals the inside look, the point of view of those who until then did not participate in the power decisions that involve society. The interest of this project lies in observing the literary framework that the book represents in the contemporary Brazilian scene. In that sense, the uniqueness of the work comes from the point of enunciation identical to that of the author; when portraying the inequality and the violence of the suburbs, the author, even if subordinated, has expressive power in rescuing the «place of speech» and displacing literary and social discourse, which historically tends to originate only from urban centers.

\section{Inequality and Violence: An Inside Look}


Writing is a practice that is not only aesthetic, but also a social posture of action. In this way, it is not enough for the writer to control discourse; he must create a space for the democratization of speech and recognize the difficulties faced in the various spheres of the literary universe.

The discussion of the thought structures within literary narratives is a necessary position, since artistic making and society have a political-historical correspondence, determined structurally by a discriminatory society. Likewise, in an attempt to grasp contemporary production, there may be possible dialogues in these areas, both regarding the legitimacy of discourse and the limits imposed on those on the fringes of these discussions; such as the individuals who are neglected by society.

Thus, when analyzing the representation and self-representation, it is possible to recognize that one receives authorization and the right to be published, that is, to be heard by society, while the other fits silence and oblivion. In addition to the problems mentioned in the previous topics of this research, there are also violence and inequality, at both symbolic and practical levels. Such problems are commonly exposed in current narratives, so they become in recurring themes. Therefore, inherent to literary production, social exclusion and its layers are represented in contemporary writing dressed as exoticism, so it is exposed from the perspective of tradition. However, the interest of this research is to verify the perception of these concepts through those who «look from within»; so, by giving rise to the interrupted voices of subordinate groups, this attitude further contributes to the thinking of national identity that has long been denied.

Furthermore, the question of the right to a voice has been the subject of controversy in contemporary society, especially because of white and male sovereignty, as well as the norm of heterosexuality. In view of this, the discussion about the place of speech becomes relevant, in order to disorganize the current principles and dislocate the unity of voice, with the objective of making possible the multiplicity of perspectives, mainly because of the pertinence of breaking with the structural power of the individual who enjoys the right to be seen as a subject in today's society.

The search for an end to the mediation of discourse invades various social practices, from the political to the literary object itself. Thus, if there is no diversity in the spheres of power, the decisions that impact society become unbalanced. The contribution of 
Djamila Ribeiro (2019) to demystify the concept of the place of speech is considered of fundamental importance. The author talks about the vagueness of the concepts of place of speech and representativeness, by pointing out that all people have the right to speech.

Therefore, it is necessary to understand that the theme of violence at symbolic, concrete, problematizing, ambiguous, and even agonizing levels is constant in the literary scenes and in the real experience of Brazilians. About this, the researcher Tânia Pellegrini (2008) clarified that violence is constitutive of Brazilian culture; in addition, the notion of violence, for the author, significantly interferes with the axis symbolic of society, being material for various artistic manifestations.

The author also talks about the historical path through which the violence followed, walking along with Brazilian history, thus serving as a literary theme. Therefore, it is possible to cite, from Pellegrini's speech (2008), the main violent scenes represented by literature throughout history, as an example: «a conquista, a ocupação, a colonização, o aniquilamento dos índios, a escravidão, as lutas pela independência, a formação das cidades e dos latifúndios, os processos de industrialização, o imperialismo, as ditaduras...» (p. 42). From this perspective, violence is a recurrent practice in Brazilian society, and it prevails in the culture in order to make people reflect on its causes and its producers, and also on how contemporary narratives include the violent expressions of the postmodern individual.

As a result, Ruben George Oliven (2010) explained that people must regard the use of violence as a substantial integral part of Brazilian culture, but quite the reverse, there is in the identity of Brazilians a false peaceful lucidity that refuses to accept the topics of a dissonant society. It is, at this point, that urban violence comes to be regarded as a serious problem and not as a treatable feature of society. Conscious of the elucidations that media manipulation provides in the spread of violence as extravagance, regarding the dominated classes, the same author noted that the violent attitude does not only translate into a superfluous practice, but also that the individual who has this stance develops in their action a political character of claim.

Given this, when talking about urban violence, the first image that permeates the thinking of society is that of the low-income gangster, usually a black man who lives in the suburbs. What Oliven (2010) pointed out are the main factors that led this individual 
to be the main focus of suspicion of violent practices, noting that the violence practiced by the lower social strata is, in fact, an attempt to reintegrate a prestigious place in society. Still, in an attempt to explain what drives the violent individual, Schollhammer (2008), in his article Breve mapeamento das relações entre violência e cultura no Brasil contemporâneo ${ }^{1}$, established a relationship between violence and cultural and artistic manifestations in Brazil. The author claimed that in the 1980s and 1990s there was a culture of claim, which resulted in an expressive cultural phenomena to this day, such as funk, train surfing and steaming.

From this reflection, it was established that the crime culture does not translate into a mere choice for the lower class youth. However, in an attempt to achieve economic gains, they end up being recruited for a high-risk life; though, this condition imposed on the young, according to the author, «[...] representa uma contestação de risco contra uma realidade percebida como injusta» (Schollammer, 2008, p. 66).

In that sense, the claim culture described by Schollammer (2008) explains much of the violent manifestations that fill the statistics in Brazil. Newspapers and television news programs interpret and speak of violence as an isolated process, and do not accept the historical factor of inequality, as founding agents of the violence that plagues the Brazilian reality.

In the hypothesis that the violence is part of a larger problem than simply a lack of character of the individual who practices it, literature, similarly, seeks to reveal the facet of this dynamic from the discourses of protagonists of this trajectory. Besides the violent history that Tânia Pellegrini (2008) portrayed in her research, there still are, nowadays, literary definitions that express the reality of contemporary violence in a less brutal way, by showing the both sides of the same coin.

If previously the demarcations of violence were drawn in the classic division: countryside versus city, this time, the stage for this expression in the form of violence requires more evident demarcations, as those dealt with in the previous topic. So, in the words of the Pellegrini (2008): «já irremediavelmente dividida em "centro" e "periferia", em "favela" e "asfalto", em "cidade" e "subúrbio", em "bairro" e "orla, dependendo o uso desses termos da região do país» (p. 44). Therefore, the nomenclature

1. Brief mapping of the relations between violence and culture in contemporary Brazil. 
that determines the new Brazilian fiction in the current instance is the rise of marginal literature.

Moreover, the relationship between contemporary Brazilian literature and urban life reflects the recurring scenes of a violent country, however what it has been exposed in the pages of many works that seek to represent the realism of cruelty are misinterpreted clichés that narrate the occurrences of a rage that pervade, mainly, in the big cities. Speaking of the marginal authors, Alva Martínez Teixeiro (2013) stated that the legitimacy of the works and the descriptions made from spaces that breathe human rawness are more than mere allegory, and bring in its conception an artistic vision related to social misery.

In this sense, Paulo Lins, in his work City of God (2012), not only shows the cruelty of human wickedness, but also seeks to portray, further, the search for happiness and hope, even though the place is a constant violent experience. Each local yearn for his or her own paradise. The violence that is narrated in the book is institutionalized; the living conditions in the slum characterize well the destination of disenchantment experienced by each resident.

So, Lins' narrative demonstrates how the world of crime and happiness in the community mingle, thus defining a universe that, while not peaceful, is livable. What Lins did in his novel is a rereading of the marginals' reality. Through an aesthetic-social game, he reveals the face of violence from the prism of truth. According to Tânia Pellegrini (2008), City of God is «um painel rude da vida na favela de mesmo nome, desenhado com base em alguns itinerários individuais, que percorrem um arco temporal de três décadas» (p. 46).

That is why so many critics define City of God only by the fatalistic side of violence, but when analyzing how each character is seduced by cruelty, it can be beheld that this encounter occurs even in childhood; such clarification confirms the brutality and oppression of the system regarding the marginal population. What Pellegrini (2008) complained about in his article, then, is the way Lins (2012) described violence. She argued that the text ends up falling into the exotic, the picturesque, and the folkloric (Pellegrini, 2008). For the scholar, violence exposed in art form, in this context, sometimes ends up reinforcing stereotypes, such as «poor» and «ugly», since the historical and social definition are not placed on the agenda. 
Contrary to what Tânia Pellegrini (2008) stated, Schollhammer (2008) developed another look at Lins' narrative. Although he also declared a certain «weakness» in the speech by the author of City of God, Schollhammer did not deny the strength of the novel and clarified that: «De todo modo, o resultado do trabalho de Lins é admirável por seu fôlego e envergadura, pelo compromisso científico e sentimental, e pelo esforço de expressão em que a crueldade da vida serve ao autor de potência poética à literatura» (Schollhammer, 2008, p. 65).

Consequently, dealing with violence in Brazilian contemporary novels becomes a task beyond allegory, and that may establish unusual definitions of understanding this phenomenon, especially if stereotypes of the poor, perceived as slum-dwelling gangsters who kill and steal are perpetuated. However, defining violence as a social problem, as established also by historical and social determinations, suggests the reflection of the need for a fair fight, as proposed by Schollhammer (2008): «...se a violência é a brutal expressão de uma ausência de negociação social, ao mesmo tempo é a demanda impotente de outra forma de simbolização, cuja energia pode ser um poderoso agente nas dinâmicas sociais» (p. 74).

As a result, literature today has a more global aspect, by being a literature that is concerned with social problems and acts in a transforming way inside this reality. The literary potential, according to Schollhammer (2008), helps in the fight against inequalities, and far from propagating prejudice; people have the appearance of reality with different political and ideological connotations that emerge from society, being the self-representation of marginalized groups in literature a form of resistance and legitimacy.

\section{The Experience of Peripheral Violence in Capão Pecado}

Socioeconomic differences difficult life conditions in the suburbs, and it is in an attempt to optimize the possibility of building a more viable trajectory that many Capão Redondo residents seek to escape extreme poverty by taking different positions along this trajectory of fight against the Government and its regulations that place them in the position of incapable, therefore marginalized individuals. 
From this angle, Arendt (2005) states, «the extreme form of power is All against One, the extreme form of violence is One against All» (p. 26). In the author's view, power needs to use violence to maintain itself, while the individual uses the same means in an attempt to restore the balance between forces.

In this sense, in Capão Redondo, to rebel against the system consists in seeking social displacement strategies, even if the approach is not violence. Still according to the author's thinking, it is evident that she works this argument by saying that «violence is by nature instrumental; like all means, it always stands in need of guidance and justification through the end it pursues» (Arendt, 2005, p. 32, emphasis made by the researchers). Going against this means, in an attempt to reach an end, Rael, protagonist of Capão Pecado, finds in underemployment an expectation to obtain justice to what is taken daily by the exclusionary system. Although it does not yield abundant profit, Rael's way of surviving dignifies life in the favela. The boy's first job was in a bakery, as the following excerpt proves: «A necessidade de roupas e de um material melhor para a escola o fez começar a trabalhar numa padaria» (Ferréz, 2013, p. 20).

Unlike Rael, other South Zone inhabitants discovered solutions that are more practical. At this point, there appears Capachão's brother, who was addicted to crack. Mariano, who has the nickname «Capachão», knew well the fate of those facing drug addiction, according to him:

[...] o caminho de seu irmão estava traçado e que o diabo o estava esperando, seu irmão não tinha mais nada em comum com aquele pequeno menino que juntamente com sua irmã tocava as companhias das casas nobres de Belo Horizonte, pulava e corria após as tocar (Ferréz, 2013, p. 32).

What is expressed in the text by Ferréz (2013) is the instructive attitude towards the problems that plague the suburbs, such as drugs, murder, and robbery. In this regard, Eble (2016) reiterated that cultural manifestations explore the tragic pathways of many protagonists, exposing a moralizing panorama in relation to their trajectories, especially the fate of those involved in crime and drugs.

Therefore, although Capachão's brother was involved in crack, it is noted that the context in which they grew up was precarious, which does not justify the fate of the brothers, but has a considerable influence on the adherence to the drug world by one of them. It is in this perspective that, from the point of view of Eble (2016), violence is no 
longer simply sensational and is understood through the prism of denunciation in relation to the contempt that the Government has regarding peripheral issues.

Opposite to his family member, Capachão faced obstacles, as when he lost his job in a tire repair shop that closed due to lack of customers, it caused his grandmother to expel him from home. Although such episodes have occurred in his life, he has not given up fighting for a better situation, that is, far from the dazzle that was the universe of crime and drugs, which presented themselves wide open to young outsiders. So, Capachão decided to take the Military Police exam, even though it is not a wellaccepted profession in the community, according to his friend Matcherros, who declined the invitation to take the exams, he said that «nunca seria um Robocop do governo» (Ferréz, 2013, p .33).

In fact, many of Rael's friends surrendered to crime and drugs. To cite one more example, in the third chapter of the book, it occurs the return of the boy's two childhood acquaintances, Will and Dida. The two brothers had disappeared from the neighborhood without leaving explanations, and upon their return they clarified that their father had had problems, resulting in the family leaving for Paraisópolis; the fact that caught Rael's attention was that «eles tinham partido havia seis meses tão saudáveis e em tão pouco tempo ficaram extremamente magros e com um aspecto de acabados» (Ferréz, 2013, p. 37). Then, Rael's mother explains why:

-É que a Maria Bolonhesa me contou muito aflita e com lágrimas nos olhos, fio, que eles se meteram com coisa errada lá pra onde haviam se mudado, e que estavam correndo risco de vida, inclusive que lá em Paraisópolis eles tão com a cabeça valendo dinheiro, por dever nas boca de fumo (Ferréz, 2013, p. 38).

Although the impetus for violence presented in the work is motivated, in some way, by the individual's relationship with drugs, Oliven (2010) argued: «Procurando enxergar a violência do ângulo do delinquente de classe baixa $-\mathrm{o}$ assaltante, o trombadinhapoder-se-ia encará-la como uma estratégia de sobrevivência num contexto onde as desigualdades sociais são gritantes»(Oliven, 2010, p. 17). This would then be the foundation of violence, in a less brutal sense, so far expressed by Ferréz, with the absence of financial comfort and the scarcity of resources to guarantee the minimum survival of the lower class subject, determining factors for development of constant violence. 
Oliven (2010) pointed out that the lack of opportunity in the so-called delinquent causes a political stance when practicing violent attacks, both in the sense of drugs, as homicide. Thus, the term marginal is usually assigned to the criminal of lower social strata, so the inability to integrate society into a dignified manner and the desperate attempt to recover what has been taken from them are potential links to the redemption of violence.

Another agent that reveals the violence in Ferréz's (2013) text, and which appears clearly, is the conception of respect within the community. Among them is a kind of pact or «slum law» that under no circumstances should there be any breaking or betrayal on the part of those involved, so as can be seen from the scenario that involved the two boys mentioned above, Will and Dida, who owed money to traffickers. In other words, it is clear that their lives were in danger, and according to the precepts of the community:

[...] as bocas não podem se dar ao luxo de ficar com prejuízo, porque senão os negócios despencam: é só uma nóia saber que tal mano comprou na boca, não pagou, e nada aconteceu, que tá feito o boato que os chefes da boca não tão com nada (Ferréz, 2013, p. 39).

In this case, Ferréz's impactful writing captures the brutal reality of the peripheral subject, by emphasizing the result of his involvement with drugs; also, the author underscores the violent consequences of crack addicts who find death for themselves and for their family. The first murder was Dida's, who was killed in front of Rael's house; the second to die was Will, whose murder occurred in the days following Dida's death: «estava com um ferimento na cabeça e ainda tremia; dona Maria Bolonhesa correu logo que soube do acontecido, abaixouse, abraçou o filho fatalmente baleado e chorou, chorou, chorou...» (Ferréz, 2013, p. 45).

Indeed, the readers rekindle the cruelty consistently described, and beyond suggestion, Ferréz (2013) constituted the bloody violence of the periphery, by narrating the disorder of the facts and the poignant aspect of criminality, and if the law of the periphery is to go against «disloyalty», Burgos, who committed the crimes in an attempt to keep respect and not be denounced, barbarously murdered the mother's brothers Will and Dida:

Depois de liberado, Raulio chegou em casa, abriu a porta e teve à frente de seus olhos a pior visão que um homem pode ter: dona Maria Bolonhesa, sua esposa, mãe de seus filhos, 
estava pendurada por um fio de cobre, amarrado ao teto, e sua barriga estava cheia de furos (Ferréz, 2013, p. 46).

Burgos, by this angle, corresponds to the true demonstration of the unworthy, mainly for going against the moralizing content that permeates the writing of Ferréz (2013). Eble (2016) pointed out that: «Assim, por exemplo, pequenos furtos por vezes são "perdoados", desde que sirvam a uma boa causa, como comprar comida para os irmãos ou um remédio para a mãe doente, numa atitude de tirar dos ricos para dar aos pobres» (p. 130).

Burgos represents the opposite of this judgment, yet there is a conscience on his part, by realizing that he has no better life expectancy far from the Capão's boundaries, and thus, his only way out is to succumb to transgressions. For him, the end is certain, and his way of gaining respect and visibility is to attack those who also have nothing. Therefore, it does not matter who he needs to kill or steal, as long as he extracts resources by exploiting the poor and defenseless. Hired by drug traffickers from Paraisópolis, Burgos makes his living by killing the residents of his own community.

Throughout the narrative, there are violent episodes dynamically described by Ferréz. What is observed is how violence is inserted in Capão's daily life, either by a homicide on the door of a resident's house, or by the body found in a water club. So, the possibilities are endless, and the search for veracity, legitimacy, and affirmation permeates the description and characterization of Ferréz's characters, by exposing the reader to a fictional as well as an undeniable atmosphere in the sense of the real.

The theme of police violence is also recurrent in Ferréz's (2013) descriptions. In this sense, Eble explained that:

Ao lado do problema das drogas, do crime e da morte, a violência policial também é uma constante nesses textos, porém problematizada sob a ótica de quem sofre essa violência, muitas das vezes, injustamente e, na maioria das vezes, em virtude da cor da pele (Eble, 2016, p. 72).

Thus, Ferréz's (2013) approach to this theme demonstrates a tinted perspective of a fierce critique of violence through power, and such scenes are recurrently glimpsed in the narrative, as in the following:

Seu Raulio foi enquadrado; ficou preso por uma semana, esperado a resposta que diria se ele havia cumprido o tempo certo de sua pena, pois havia a possibilidade de ele ter saído em razão de uma fuga. A resposta chegou e ele foi finalmente liberado (Ferréz, 2013, p. 45). 
In the case above, prejudice against the former prisoner consisted of an excess on the part of the authorities, in addition to the fact that the individual suffered from exclusion. In general, even if he has already served the sentence, he was subject to various kinds of withdrawal from society, such as inconsistent suspicions of escaping from prison. In addition to this more symbolic form of violence, there were several attitudes police officers had toward the community, especially when using their position to confront crime. Whether through excessive use of force or verbal intimidation, these actions reach the population without moderation in a lethal manner. Encouraged by the system, it is convenient for them to handle all kinds of abuse, as happened when the police aggressively invaded the community, frightening residents with the excuse that they were fulfilling their role, so women were also victims of violence, via sexual abuse and other mistreatments.

It is interesting to note that one of the police officers involved in this abusive operation in Capão Redondo was Mariano, who had the nickname Capachão, precisely because it is now seen on the other side, being a kind of «system doormat», corroborating to reduce the chances of the poorest. In exchange for the money, he sacrificed the most important good of the community, honesty: «Ao fundo Matcherros notou um gambé com o cassetete na mão, e mesmo com a cabeça baixa percebeu ser seu amigo Capachão» (Ferréz, 2013, p. 166).

Then, the protests against police violence were even more bigger, and symbolic power is reaffirmed when the police head towards the hill and weave a chaotic picture around the community, and it is upon the hill that the police find a bar that was a point meeting place for people to have fun with, but the rap lyrics, which criticized exactly the situation that was taking place, made the officers feel even more irritated: «O som, antes de ser interrompido por motivo de perfuração à bala, bradou o último verso: "Não confio na polícia, raça do caralho"» (Ferréz, 2013, p. 166).

So, the process of building a space conducive to violence in its many facets is no coincidence; the negative valuation with which the marginal man is treated stimulates the symbolic and prominent violent precedents towards the physical and brutal attack, as is the case. This is the case described in the passage above; where the narrator reveals the fierce manner in which police officers react to a simple «loud volume». Since «A violência que se vive hoje no Brasil não vem do nada, nem de fatores que não sejam já 
conhecidos, embora possam ser ignorados» (Pino, 2007, p. 771), it is evidenced that the violent nature goes beyond the purely bias transgressor and invades political and economic links.

Meanwhile, the power of the suggestion of violence in Capão Pecado goes beyond what it is understood as generating aspects of violence, the forbidden love itself seals the cruel fate for some characters. Romance is a very significant theme in the narrative, even though Rael is a friend of Matcherros, he ends up getting involved with his girlfriend, Paula. The desire for the girl arose from the first contact with her at work, as can be seen: «durante o restante daquele dia não pensou em mais ninguém, não conseguia apagar de sua mente aquele rosto iluminado pelo sol, aquela boca úmida que parecia pedir um grande beijo» (Ferréz, 2013, p. 57). There is no doubt that violence involved in love relationships crosses the ages, being the barbarism that involves the lovers in a violent sentence that is pointed out in their stories. In short, Rael and Paula symbolize the love theme in this fatalistic perspective.

Now, by getting involved with his best friend's girlfriend, Rael is no longer a linear and predictable character, so he is being guided from that moment on by his desires and impulses. Likewise, Capachão, he undermined an essential value of the community: «... a periferia como lugar de identificação aparece de várias formas; uma delas é a relação de amizade, sendo o espaço da periferia onde os "manos" reconhecem seus companheiros...» (Eble, 2016, p. 95). In this excerpt, the author explains that the relations of respect and friendship in the favela are a matter of principles, so the misconduct linked to the betrayal of such values consists in attitudes of revenge.

Later on, after discovering the betrayal of his friend, Matcherros states: «Da trairagem, nem Jesus escapou» (Ferréz, 2013, p. 167). Despite the breakup of their friendship, Rael seemed to have managed the structure of his life with the family he had formed with Paula, but the girl describes in the book what follows its course of betrayal by getting involved with Rael's boss, Mr. Oscar. In this case, Paula breaks with the stereotype of a subjugated woman and a victimized subject in the midst of society, even composing a double condition of exclusion: woman and peripheral. In this sense, Ferréz (2013), while not focusing on female roles in Capão Pecado, seeks not to imprison the female figure in essential categories, by giving space to the multiplicity and uniqueness of being a periphery woman. 
Thus, violence in this context arises from betrayal, both in the love relationship and in the principle of friendship. Upon discovering that Paula was cheating on him and had abandoned him, in a fit of rage and revolt, Rael is fired and begins his revenge:

Burgos lhe explicara tudo, como proceder, e agora era só esperar. Seu Oscar desceu do carro e estava abrindo a primeira porta da metalúrgica. Burgos estava do outro lado, Rael ia fazer por vingança, pela honra; Burgos ia fazer pela grana. Burgos o rendeu facilmente com uma pistola F.N. modelo 1903 calibre $9 \mathrm{~mm}$, que fora desenhada pelo Exército belga, o empurrou para dentro do escritório. Rael adentrou a metalúrgica e seu Oscar suou frio quando o viu com uma calibre 12 nas mãos (Ferréz, 2013, p. 177).

In this situation, Rael's decay toward evil is suggested from his involvement with Burgos, known as the «demon» of the community. In relation to this irrational thought which is designated from violent attitudes through individuals, Pino (2007) stated: «Ora, se a violência é irracional, não é por ser obra de um ser desprovido de razão, mas por ser, paradoxalmente, o produto de uma razão perigosamente racional» (p. 769). Therefore, the character's transgression comes as a disappointment to the narrator himself, describing that «Rael se esqueceu de Deus, de sua mãe e das coisas boas da vida, apertou o gatilho e fez um buraco de oito centímetros na cabeça de seu Oscar» (Ferréz, 2013, p. 178). So, by not accepting the inferiority condition imposed on him through his boss' betrayal, he submerged himself in the context of crime, and the tragic outcome is death, when the neighbor who witnessed the scene «entrou em casa, ligou para a polícia e ferrou mais um irmão periférico» (Ferréz, 2013, p. 178).

The tragic and violent end reaches the two characters, with their cross stories, Rael is killed in jail by Burgos' cousin, and then Burgos is killed by the police. The cycles of violence invade the daily life of Capão Redondo neighborhood, being common for the characters to live with the world of crime, and despite attempts to dodge it, the tragic fate pursues each of the characters.

As a result, the debate about the violent context of the neighborhood includes variants beyond financial difficulties, the meaning of thug life translates into numerous survival relationships, and one of them is violence, as alluded to by Eble (2016): «A violência recebida sob a forma de exclusão, humilhação, discriminação e até mesmo extermínio da juventude negra, é devolvida sob a forma de resistência» (p. 147). In this sense, the hope of peace in the periphery remains. Finally, in the last chapter of the book, this possibility is taken as a dream, but to dream on the periphery is to have the eyes wide open and the feet on the ground: «-Só, choque! Eu também tô nesse 
sossego, mas é o seguinte, eu sempre procuro o bem, tá ligado? Mas se o mal vier, choque, que o Senhor tenha misericórdia» (Ferréz, 2013, p. 186).

\section{Conclusions}

The expressive power that marginal literature represents in contemporaneity is part of a broad aesthetic project that continues to grow. What it was observed through the analysis proposed in this study is that the literature made by Ferréz, which has as its characteristic the collectivity in the aesthetic construction of his texts, as well as the language of the periphery, tends to function as a rescue of the culture of the suburbs.

However, combative literature is not the author's main commitment, but living in Capão Redondo makes him a direct member of this movement, even though he does not take responsibility for writing only for this purpose. The author represents, therefore, voices that in Brazilian literature, for a long time, faced silence and forgetfulness, but today can, even with difficulty, express positions in the literary field.

From this study, it may be established that the reality experienced by the author has been increasingly pointed as a support for legitimation to represent realism in the literary universe, especially if it is considered literary work as a tool for social transformation. Thus, there is an increasing interest in questioning the representations made in narrative compositions, when these come from places of speech as distorted as if readers read the speech of a man trying to explain to a woman what it would be like to suffer with a highly patriarchal society, or a white man trying to express the suffering and difficulty originating from racism to a black person, given the historical factors so fiercely defined by Brazil's situation as a country that used slavery as a trigger to propagate spheres of prejudice, that have left severe marks to this day.

Therefore, discussions about the periphery, inequality and violence that appear in the writer's speeches highlight the aspect of lack that surrounds Ferréz's geographical locus of enunciation, reinforcing the angle of literary self-representation, precisely because living in the periphery is experiencing situations of marginality. Therefore, the theme of violence in Capão Pecado breaks with the exoticism with which this theme is approached by both the media and literature. Being social inequality, unemployment, lack of public assistance, factors that induce violence in the peripheral regions, and as 
discussed by Oliven (2010) and Pellegrini (2008), violence is still fundamental to the identity construction of Brazil.

The book assumes a position, not of denial, but of affirmation of violence, as a real problem of the peripheries. However, it obliges society to see this manifestation in another way, through the contemplation of those who are induced, through the actions of the system, to respond to police violence against them, with a violent response, which for such individuals is often the only alternative.

\section{Bibliographical References}

1. Arendt, H. (2005). On Violence. Recording for the Blind \& Dyslexic.

2. Eble, L. J. (2016). Escrever e inscrever-se na cidade. Um estudo sobre literatura e hip-hop. $200 f$. (Tese de Doutorado). Universidade de Brasília, Brasília. Recuperado de: http://repositorio.unb.br/bitstream/10482/23045/1/2016_LaeticiaJensenEble.pdf

3. Ferreira da Silva, R. (2000). Capão Pecado. São Paulo: Labortexto Editorial.

4. Ferreira da Silva, R. (2013). Capão Pecado. São Paulo: Planeta.

5. Ferreira da Silva, R. (2016). Manifesto de abertura: Literatura Marginal Terrorismo Literário. Literatura Marginal. Recuperado de http://editoraliteraturamarginal.blogspot.com/2006/12/manifesto-de-abertura-dolivro.html

6. Hall, Stuart. (1997). Representation: Cultural Representations and Signifying Practices. London, Thousand Oaks and New Delhi: Sage Publications/Open University. 7. Lins, P. (2012). Cidade de Deus. São Paulo: Planeta.

8. Nascimento, É. P. (2006). “Literatura Marginal”: Os escritores da periferia entram em cena. 2006. 197 f. (Dissertação de Mestrado). Faculdade de Filosofia, Letras e Ciências Humanas da Universidade de São Paulo, São Paulo. Recuperado de http://bdtd.ibict.br/vufind/Record/USP_e26964319e842ebf6fc60bced30ef85e

9. Oliven, R. G. (2010). Violência e cultura no Brasil. Biblioteca Virtual de Ciências Humanas. Rio de Janeiro. Recuperado de http://books.scielo.org/id/b8n7j

10. Patrocínio, P. R. T. (2013). Escritos à Margem. A presença de autores de periferia na cena literária brasileira. Rio de Janeiro: 7Letras: Faperj. 
11. Pellegrini, T. (2008). No fio da navalha: literatura e violência no Brasil de hoje. In Dalcastagnè, Regina (Org.). Ver e imaginar o outro: alteridade, desigualdade, violência na literatura brasileira contemporânea. São Paulo: Horizonte-SP.

12. Pino, A. (2007). Violência, educação e sociedade: um olhar sobre o Brasil contemporâneo. Educ. Soc., Campinas, 28(100), 763-785. Recuperado de http://www.nescon.medicina.ufmg.br/biblioteca/imagem/1012.pdf 13. Ribeiro, D. (2019). Lugar de Fala. São Paulo: Sueli Carneiro; Pólen.

14. Schollhammer, K. E. (2008). Breve mapeamento das relações entre violência e cultura no Brasil contemporâneo. In Dalcastagnè, R. (Org.). Ver e imaginar o outro: alteridade, desigualdade, violência na Literatura brasileira contemporânea. São Paulo: Horizonte-SP.

15. Schollhammer, K. E. (2009). Ficção Brasileira Contemporânea. Rio de Janeiro: Civilização Brasileira.

16. Teixeiro, A. M. (2012). A plenitude de um vazio em que a pobreza não é mais paisagem: a periferia em Paulo Lins e Ferréz. Estudos de Literatura Brasileira Contemporânea, Brasília, (41), p. 61-86. Recuperado de: http://www.scielo.br/scielo.php?pid=S2316$40182013000100005 \&$ script=sci_abstract $\&$ tlng=pt. 